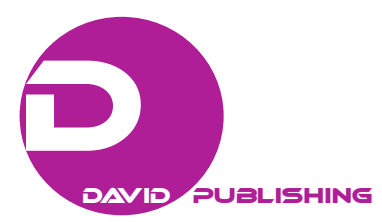

\title{
Treaty on the Prohibition of Nuclear Weapons: The Ban and Limits Thereof
}

\author{
Erkan Akdogan \\ Ankara University, Ankara, Turkey
}

\begin{abstract}
Treaty on the Prohibition of Nuclear Weapons is a fact. Being a treaty, it has consequences on the intersection of diverse fields, including but not limited to nuclear physics, nuclear defense industry, peace or disarmament studies, international law and so on. Although being at such intersection itself, resembling nuclear forensics, legal issues arising out of the Treaty, e.g. the object and purpose thereof, the ban provisioned thereby and other symbolic legal problems need to be addressed in order to further assess of the significance and understand of the Treaty. In this study, it is purported to attract the attention of scientists from different fields to some key legal, social, and humanitarian issues pertaining to the Treaty, though legal doctrine itself is generally inattentive vice versa.
\end{abstract}

Keywords: general theory of law, international law, nuclear disarmament, arms control, Treaty on the Prohibition of Nuclear Weapons

\section{Introduction}

In a world, or a web of science where things are best understood within the confines of a "technical" vocabulary, it is rather unusual to address issues at ethical, legal, or philosophical crossroads. And, when this is purported or at best, achieved, it is seldom done in a predictable fashion, devoid of considering implications or of its meaning in other fields.

Being conceived in this way, the nuclear energy, as a "dual-technology", may stand as a supplement to various discourses, fields of study, scientific disciplines, and so on. It may be a "supplement” (Derrida, 1997, pp. 157-164, 280-295; 1981, pp. 95-119, esp. 108-112) ${ }^{1}$; on the one hand, it functions as an addition to the main discourse on physics, natural or nuclear sciences in general. It is their condition, the ultimate point thereof. On the other, it operates as a substitute, pertaining to the ultimate goal of the pacifist movement, or, general and complete disarmament. As such, it is possible to notice that the premises of these two stances, at their fundamental assumptions, seem to contradict each other (Kennedy, 1987, pp. 1-20, 218; UNOLA, 1999, pp. 495-523; Frankenberg, 2014, pp. 1-29) ${ }^{2}$. The first one assumes that with the advent of science of technology,

Erkan Akdogan, Ph.D. candidate, School of Social Sciences, Ankara University; research assistant, Department of International Law, Law Faculty, Ankara University, Ankara, Turkey.

Correspondence concerning this article should be addressed to Erkan Akdogan, Ankara University Law Faculty, Cemal Gursel Cad. No: 58, Cebeci 06590, Cankaya, Ankara, Turkey.

${ }^{1}$ On "supplement", see Derrida. The Bluebook is followed herein, unless otherwise mentioned, cf. The Bluebook: a Uniform System of Citations, Twentieth edition, Cambridge, The Harvard Law Review Association, 2015. References herein to works in different languages are made with respect to their difference. Translations are made by author unless otherwise mentioned.

${ }^{2}$ On this see esp. (for the concept and operation of expert rule) Kennedy, or (for different roles and identities in the legal doctrine, as typified by the judge, the adviser, the activist and the academic) Koskenniemi. But (for basics of the mentality of political executives and engineers, and their shared modus operandi) see also Frankenberg. 
humanity or our conditions of life would progress as well. However, in the second stance, e.g. from the perspective of pacifist movement, optimist scientism leaves the scene to scenarios of catastrophe. For the adherents to this perspective, as far as the science and technology progress, such progress also connotes that weapons technology and inhumane weapons would make progress as well. In such flux and conflict of ideas, representations and positions, one is tempted to introduce also the "supplementarity" of international legal issues pertaining to nuclear energy itself.

Another way to approach this contingency, since there exists much more than depicted here, is to conceive such issues in a rather sociological perspective. Namely, e.g. by observing the observers, trying to conceive at least why and how in distinct "field"s of study, composed of men, and generally they are all men, communicating the same language and sharing a distinct vocabulary, the way problems are posed and are dealt with, the positions in a given field are structured structuring such opinions, the nomination is operated, the unequal division of work and cultural capital tend to perpetuate etc. (Bourdieu, 1995, pp. 1-30). Understanding in this way, one can combine the two perspectives mentioned above in order to attain a picture of what is at stake in a scientific discussion. For instance, from the point of arms control or disarmament, international legality is itself a supplement in both senses, the rules and principles of international law appear, mostly, as instruments that purport to let the arms control or disarmament realize. Conversely, confiding in and suppressing its structuration that structures itself ethically, the discourse on nuclear sciences, in all its technicality and language, presents a neutral, an objective discourse in itself whereby the legal and other aspects thereof are totally excluded, or implied. Put simply, in nuclear sciences, the discourse is thought to be formed objectively, depoliticized and open to research and innovation as distinct from those legal and other social or humanistic disciplines whereby the object of study is doubly connected with the field, the object of the study itself. It is in this vein that, for instance, nuclear forensics operate in the context of law enforcement or the nuclear security (IAEA, 2006, p. 3), and, in our opinion, vice versa. This study aims to show, in very simple and basic terms, modus operandi of the legal side of the story about ban on the nuclear weapons. Whereas it is intended to hint, whenever possible, at different aspects of such a complex issue, namely, prohibition of nuclear weapons as exemplified in the Treaty on the Prohibition of Nuclear Weapons ("Treaty”).

\section{Brief Outline of the Legal Framework}

As per a renown Judgment of the International Court of Justice (1986, ๆ 269),

(sic) Since in international law there are no rules, other than such rules as may be accepted by the State concerned, by treaty or otherwise, whereby the level of armaments of a sovereign State can be limited, and this principle is valid for all States without exception.

Thus, in other words, the World Court opines that any state, by its very definition or by being a state, is entitled to organize her army, military structure, and force (=arm how you want unless you do not want otherwise). This is the foundational principle, or to put it better, condition of the discourse on arms control (Tuzmukhamedov, 2015) and disarmament (Fisher, 1971)².

From another point of view, whatever terminology we adopt, recourse to war, armed conflicts or use of force, since it proved impossible in fact to eliminate these in international politics, in "Paris Law", the right to

\footnotetext{
${ }^{3}$ For Fisher, to start a discussion on outlawry of war or disarmament, one would rather examine first, "one of our oldest nternational legal institutions-the treaty or international agreement...it must deal realistically with the extent to which one can expect a sovereign State to live up to a treaty which appears to be contrary to its supreme national interests”, ibid.
} 
self-defense is recognized along with the prohibition of use of force ${ }^{4}$. Among many problems inscribed to the core of the law on force (Berman, 2004-2005; Kennedy, 2006), let us follow a brief logico-philosophical exercise as a hint, but only a hint to the logic of use of force. As Kant put it with regard to ius strictum, although violence is prohibited in order to attain liberty to use a right, when any excess on the use of a right would constitute itself a breach of another right and be illegal, violence against the first one would be legal under ius strictum.

In line with the above, when our focus shifts to international humanitarian law, we face with yet another plurality of laws. As the Court notes in Nuclear Weapons Opinion, (i) "Hague Law" "fixed the rights and duties of belligerents in their conduct of operations and limited the choice of methods and means of injuring the enemy in an international armed conflict" whereas (ii) "Geneva Law" "protects the victims of war and aims to provide safeguards for disabled armed forces personnel and persons not taking part in the hostilities"5. In other words, these two bodies of law complement each other in order in a way to promote humanitarianism in war, under which universal values come before law or in some cases such values cancel law (Peters, 1996) ${ }^{6}$ (=you are allowed to kill but you do not have to kill everyone; do not injure but kill when you are allowed to). In this sense, to both, use or threat of nuclear weapons may much more easily be found illegal.

However, taking Paris Law into consideration, the Court fell short of denouncing nuclear weaponry. In Court's modus operandi, since it is a court whose primary function is to "administer justice based on law"7, she declared that

(sic) In view of the present state of international law viewed as a whole, as examined... by the Court, and of the elements of fact at its disposal, the Court is led to observe that it cannot reach a definitive conclusion as to the legality or illegality of the use of nuclear weapons by a State in an extreme circumstance of self-defence, in which its very survival would be at stake. (Nuclear Weapons Opinion, 1996, ๆ 97)

In other words, the law on use of force is interpreted by the Court as to allow a nuclear weapon state to counter an attack by nuclear weaponry in special circumstances, though in general their use would be contrary to international humanitarian law or human rights law. Since, as one turns to human rights in law, one is told by the Court that some are also valid in war: There are, other than those rights exclusive either to international humanitarian law or to human rights law, still others that "...may be matters of both these branches of

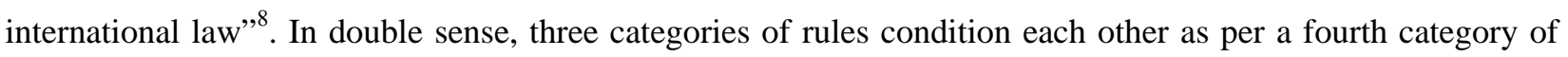
rules which define when to refer to which category.

\footnotetext{
${ }^{4}$ Nicar. v. U.S.A., I 269. For the World Court, taking into consideration that the US reservation to the Court's jurisdiction, prohibition to threat or use force is also part and parcel of international law, ibid., $945,56,172$. The Court seems to opt for relying solely on treaty law whenever possible while announcing that for a state against whom force is used, other than self-defense (esp. UN Charter, Art. 51), there are “(o)ther means...available..., including, in particular, recourse to the Security Council” of the UN, cf. e.g. Case Concerning Armed Activities on the Territory of the Congo (Dem. Rep. Congo v. Uganda), Judgment, 2005 I.C.J. Rep. 168, ๆ 148-149, 164-165 (December 19). The Court declares also that not any use of force would constitute a breach of the law, however. For a breach to occur, use of force would have "such a magnitude and duration”, ibid., I 165. On Paris Law, cf. Corten (2005).

${ }^{5}$ Legality of Threat or Use of Nuclear Weapons, Advisory Opinion, 1996 I.C.J. Rep. 226, ๆ 31, 75 (July 8). This Opinion has been extensively discussed, harshly criticized and there exists a vast literature on the subject. We-perhaps we should first define who we are-rather refrain from further elaboration thereon in order to try to demonstrate what ensures such scholarly discussion.

${ }^{6}$ For Peters: “...Delegates schooled in disarmament control used a well-known argument that an international humanitarian law treaty... such as the CCW only restricts the use of certain conventional weapons...”, ibid.

${ }^{7}$ Aerial Incident of July 27th, 1955 (Isr. v. Bulg.), Preliminary Objections, 1959 I.C.J. Rep. 127, 192 (May 26) (Lauterpacht, Woo, Spender diss.).

${ }^{8}$ Conséquences juridiques de l'édification d'un mur dans le territoire palestinien occupé, Avis consultatif, 2004 I.C.J. Rep. 136, ๆ 106 (Juillet 9). The Court in 2004 followed the line of thought in Nuclear Weapons Opinion, ๆ 25.
} 
As already noted by many commentators (Weil, 1998), the above mentioned quotes from Nuclear Weapons Opinion are perfect instances of non-liquet. Unable to take a stance outside the legal vocabulary, the Court seemed trapped in the same without being able to excess the dividing line of the legal from the non-legal, and those lines dividing the international legal doctrine. Open to criticism from different perspectives, anti-nuclear activists to pro-nuclear militarists, the Court indeed chose to imply reference to her own premise that enabled herself, to defer the solution of the difference to another forum or to advise by negation (Koskenniemi, 1999, p. 501) ${ }^{9}$. In another sense, to us, the Opinion presents an example of self-reference embedded in the modern understanding of law. We are of the opinion that in her declaration of such non-liquet and advising by her very negation to respond in law, the Court reiterated the basic source of the law, or legal doctrine itself: the utmost violence which is inscribed at its core. To some, this may appear as cynicism, but in it we can see another aspect of the problem. Let us think about the judges in the Hague in 1996. How could the Court have opined otherwise? Had the nuclear weaponry been outlawed once and for all in an Opinion by the Court, not only nuclear industry and nuclear sciences would be jeopardized but also the Court would bind sovereigns without or explicitly contrary to their own consent. In sum, being doubly-bound, the Court implied that "law is law": It is indeterminate in such a way to define who are the judge, the judged, and the victim, and, determinate in being unable to denounce its own source that enables it (Lyotard \& Nancy, 1985, not. pp. 115, 119, 121-122; Zizek, 2008, pp. 95, n. 35, 203-209, 226-227, n. 30; Chazel \& Commaille, 1991, pp. 95-99, not. 96; Deleuze, 1993, not. pp. 7-41) ${ }^{10}$.

From legal or institutional point of view, whereby any issue is conceived as "legal", nuclear energy is a "legal" concept. It is a concept to which an "internationality" is ascribed via different legal techniques, e.g. an international organization established with a treaty, dependent on new treaties or arrangements, backed up with a treaty body or mechanism, and ensured by constant diplomacy. An example is International Atomic Energy Agency ("IAEA"). Being created before but affected functionally by adoption of the Treaty on the Non-Proliferation of Nuclear Weapons ${ }^{11}$ ("NPT"), IAEA has a complex set of agreements and arrangements which require in-depth research and analysis to construct the applicable law to a specific state. This complex modus operandi, we presume, is backed up by the framework within which the Agency is destined to function as well. For instance, NPT's main provisions (Articles 9(3); 1, 2) enable nuclear arms exclusively to five(5) states, namely the United States of America, the United Kingdom, France, Russian Federation (Russia), and the People's Republic of China (China). As such, this aspect of the issue seems to coincide with the stance of the World Court on the level of armaments mentioned above. Furthermore, from the point of view of the IAEA, a state party to the NPT and a member of the IAEA, by being a party and a member thereto mean legally that such state is not unlimited in its discretion to develop nuclear energy so as to improve nuclear weaponry. In such scheme, it has been possible for several states to stay out of the NPT and IAEA such as Israel, or, withdraw from its membership so as to legally avoid the implications of the scheme itself, such as North

\footnotetext{
${ }^{9}$ One way to conceive this is to interpret this part of the Opinion through the self-image of the Court, and identity of the judge apart from a moralist or a humanitarian, see Koskenniemi, p. 501.

${ }^{10}$ For an assessment, insight and critique, cf. Derrida, Préjuges: Devant la loi dans Lyotard et al., and Zizek. This “double-bind” may be, in a specific sense, termed as "collective hypocrisy" as well, cf. Bourdieu, Les juristes, gardiens de l'hypocrisie collective dans Chazel, Commaille. For an introduction to the repetitions and differences, cf. Deleuze.

${ }^{11}$ For text, States Parties and info shared by the UN Secretary General, $c f$. id., Treaty on the Non-proliferation of Nuclear Weapons, submitted by the USA, the UK and USSR, available at: <https://treaties.un.org/pages/showDetails.aspx?objid=08000002801d56c5> [17.11.2017].
} 
Korea $^{12}$.

Adopted at the United Nations (UN) Conference on July 7, 2007, the Treaty ${ }^{13}$ aims first and foremost to address the issue which, in the Nuclear Weapons Opinion outlined above, has remained unclear or ambiguous, and that left the way open for the five states mentioned in the NPT along with those who stayed out thereof to use their nuclear weaponry in a limited number of, but still indeterminate cases. In other words, in the 21st century international imagination, by international legislation enacted by states the things as they stand are attempted to be changed, state of things itself as a creation of other states or the international community within which such change is aimed at. Activism, to attain a legal result, transforms into a variant of "pactomania" of inter war international legalism. In order to assess what is achieved in concreto by such international legislation that international adjudication could not around 20 years ago, we may read the Treaty briefly.

\section{In a Nutshell: Object and Purpose of the Treaty, Architecture of the Ban}

In treaty law, rules, and principles applicable to treaties themselves, object and purpose of a treaty is, at its core, a limit whereby the freedom of state activity in relation to treaties is purported to be negated or limited pertaining both to the treaty and other states parties as well (Kennedy, 1987; Carty, 1991; Kolb, 2001) ${ }^{14}$. Put simply, lacking a strict description or a precise formula of its own, object and purpose of a treaty functions as to fill, to defer or to delay the gap created by the text of a treaty, open to interpretation or contest by states parties, practitioners, treaty mechanisms and bodies along with international organizations, and though marginalized, courts and tribunals. Generally to be found in its Preamble or travaux préparatoires, the object and purpose of a treaty functions as a guide for interpretation or legal construction of a treaty ${ }^{15}$.

The Treaty as such, is based upon several principles as stated by the States Parties in its Preamble. For instance, States Parties, "basing themselves" on the rules and principles of international humanitarian law, in their view, which delimit "the methods or means" to be used in warfare, find any use of nuclear weapons to be contrary to rules of international law applicable in armed conflict, as well as any use thereof would constitute abhorrence to "the principles of humanity and the dictates of public conscience”"16 (Preamble, ๆ 10-12). Since, not only international humanitarian law consists of rules such as "the rule of distinction, the prohibition against indiscriminate attacks, the rules on proportionality and precautions in attack", but also "the prohibition on the use of weapons of a nature to cause superfluous injury or unnecessary suffering, and the rules for the protection of the natural environment” necessitate the ban of nuclear weapons (Preamble, I 10). When used, nuclear weapons would bring "catastrophic humanitarian consequences", even having them in possession would pose serious "risks", the issue presents problems tied to "human survival, the environment, socioeconomic development, the global economy, food security and the health of current and future generations, and have a

\footnotetext{
${ }^{12}$ For the comprehensive list of members, including those who withdrew their membership to the IAEA, cf. IAEA, List of Member States, <https://www.iaea.org/about/governance/list-of-member-states> [17.11.2017].

13 Treaty on the Prohibition of Nuclear Weapons, UN Doc. A/CONF.229/2017/8, 07.07.2017, available at: http://undocs.org/A/CONF.229/2017/8> [17.11.2017]. All references herein are to the Treaty, including Preamble and Articles, unless otherwise mentioned.

${ }^{14}$ Réserves à la Convention pour la prévention et la répression du crime de Génocide, Avis consultatif, 1951 ICJ Rep. 15, 26 (Mai 28). Law of treaties, or, sources discourse in general is a kernel of international legal scholarship in general. On the discussion itself compare, e.g. Kennedy and Carty. Among numerous attempts to overcome such flux, see e.g. Kolb.

${ }^{15}$ On this see e.g. Rights of Nationals of the United States of America (France v. United States of America), Judgment, 1952 I.C.J. Rep. 176, esp. 184, 197 (August 27).

16 This expression and its broader meaning, willingly or unwillingly, connotes attachment to doxa that found its expression in the dictum of the World Court in Reservations Opinion, p. 23.
} 
disproportionate impact on women and girls, including as a result of ionizing radiation” (Preamble, \ 3, 4, 5).

The efforts on general and complete disarmament have been an issue, though highly contested since the beginning of the 20th century, especially the Hague Peace Conferences (1899 and 1907, respectively). Seeing the war inevitable and the advance of the war industry and armament race insurmountable, the experiments of Versailles and Geneva, the response of the legal doctrine was to try to find a way to deal with issues on disarmament and to put forward arms control (Wehberg, 1919). After the World Wars and the advent of the UN, arms control became an intermediary between "total war" and "general and complete disarmament", between policy options to use nuclear weapons in a surprise pre-emptive attack or within an ongoing hostility (Goldblat in Spillmann \& Wenger, 1999, pp. 65-66). Given the fact that up until 1970s, not only the US but also the states mentioned above acquired nuclear weaponry and with the introduction of the NPT, throughout the Cold War, the arms control had been conceived as a matter of bilateral (US and Soviet Russia), rather than multilateral arrangements, and for the humanitarian activism, this was seen as the main obstacle of general and complete disarmament. However, States Parties to the Treaty, mindful of "the slow pace of nuclear disarmament, the continued reliance on nuclear weapons" in current political discourse and "the waste of...resources on" nuclear weapons, preferred a "legally binding prohibition of nuclear weapons" (Preamble, I 15, 16). Nevertheless, the States Parties excluded categorically "the inalienable right of" themselves "to develop research, production and use of nuclear energy for peaceful purposes without discrimination” (Preamble, ๆ 22). Wherefore, implementation transforms to "verification" and “costs” thereof (Preamble, ๆ 19; also cf. also Articles 4, 8(b), 9(3)).

What are those states and States Parties? How did they vote in the conference? As per the data provided by the UN Secretary General, the Treaty has been signed by 53 states, three ratified ${ }^{17}$. At the end of the Conference, the final vote on 7 July 2007 comprised of 122 affirmative, one negative (Netherlands), and one abstaining (Singapore) ${ }^{18}$. Strikingly, while Iran voted affirmative, none of the known or unknown nuclear powers (the US, the UK, France, China, Russia along with India, Pakistan, Israel, North Korea) participated in the UN Conference. In sum, whatever the drafters have intended, the initial outcome is of an ambiguous character that hampers the object and purpose of the Treaty itself: The nuclear weapons are legally declared illegal, but the ban is not legally binding on nuclear powers who hold nuclear weapons legally (Please note that though repeated three times, each "legally" connotes a different meaning). This result, in our opinion, is without doubt a further step than Nuclear Weapons Opinion. However, in concreto the problem of general and comprehensive nuclear disarmament remains. Let us turn to text of the Treaty to gain a picture of such effort.

The Treaty prohibits seven categories of acts, actions, or inactions by the States Parties. First category includes development, test, production, manufacture, acquisition, possession, or stockpile of "nuclear weapons or other nuclear explosive devices” (Art. 1(a)). In actual wording thereof, development, test, production, manufacture are followed by "otherwise acquire, possess, or stockpile" which, in our opinion, marks interchangeability with the first part of the phrase and all inclusive. The Treaty also envisages declarations to be submitted thereof to the depositary, namely the UN Secretary General, that in turn shall provide the remaining States Parties with such declarations made (Art. 2). If any State Party holds any nuclear weapon or device as

17 UN Secretary General, Multilateral Treaties deposited with Secretary General, Chapter XXVI.9, available at: $<$ https://treaties.un.org/Pages/ViewDetails.aspx?src=TREATY\&mtdsg_no=XXVI-9\&chapter=26\&clang=_en> [17.11.2017].

18 UN, Conference to negotiate a legally-binding instrument to prohibit nuclear weapons: Item 9, UN Doc. A/CONF.229/2017/L.3/Rev.1, available 
such falling under this category, such state shall abandon its nuclear programme "prior to the entry into force of the Treaty for it", and "cooperate with the competent international authority" or "authorities" designated by the States Parties as per Art. 4(6) (Art. 4(1)). By this, among others, the resolution of the problem is deferred to future decision making and institutional operation, as was the case for chemical weapons.

Second category of undertakings includes, the ban of "transfer to any recipient whatsoever...directly or indirectly” (Art. 1(b)). In other words, the States Parties undertake not only to test, produce, hold, or possess but also to transfer nuclear weapons or devices as such to any other "recipient", which denotes not only states but also non-state entities, including private organizations, movements, individuals, and so on. With this, state action turns to non-state sphere to ensure the outcome it is directed at. This is complemented by the third undertaking that includes the ban of "reception" itself, which means the ban to "receive the transfer of or control over" nuclear weapons or devices as such (Art. 1(c)).

Fourth undertaking, linked directly with the Nuclear Weapons Opinion, bans any use or threat to use nuclear weapons or devices as such in line with the understanding mentioned in the Preamble (Art. 1(d)). Furthermore, fifth undertaking provisions a ban to "allow any stationing, installation, or deployment of any nuclear weapons or other nuclear explosive devices in its territory or at any place under its jurisdiction or control” (Art. 1(g)), by which it can be interpreted so as to purport to delimit the ban geographically, namely, on the territory whereby the State Party is assumed to perform sovereignty or control as such.

Last but not least, the other two categories include on the one hand, the ban of assistance, encouragement, or induction, "in any way, anyone to engage in any activity" is already banned by the Treaty (Art. 1(e)). And, on the other, seeking or reception of any assistance, "in any way, anyone to engage in any activity" is already banned under the Treaty as such.

In order to implement the ban, "necessary measures" shall be adopted by the States Parties, and "all appropriate legal, administrative and other measures" shall be taken to ensure the prohibitions summarized above (Art. 5). States Parties undertake to cooperate for these purposes as well (Art. 7, 12). To further assess the implementation, along with other issues, the "Meeting of States Parties" is provided, that shall be held "regularly in order to consider, and, where necessary, take decisions in respect of any matter with regard to the application or implementation of” the Treaty (Art. 8).

In summary, the Treaty itself bans, prohibits, orders along with deferral, referral, intervals to implement, to realize its object and purpose. In order to achieve them, not only States Parties, but also other "actors", non-state entities are needed crucially, by the same wording and spirit of the Treaty. And, although the non-participant nuclear powers hampered the effect of the Treaty, this crucial need requires to be filled and will allow space to further the work, still unfinished and rudimentary, but invaluable and ambitious.

\section{Conclusion}

To conclude, it would be turn to the themes touched upon in introduction. In such sense, the lines dividing the legal and physical spheres, jurisprudence and nuclear sciences, humanities and natural sciences are of considerable size and effect. When an issue is taken in a sphere or field as such, the outcome is generally predictable, e.g. in legal sphere, it is easy to predict that the narrative would be about rules, principles, courts, states, organizations, interpretations as well as exceptions, litigants, object-and-purposes. The Treaty itself presents an example for these remarks. Namely, an all-inclusive ban would prohibit any nuclear science in general and comprehensive way, since, at least from the experience of the IAEA we know that it is not 
relatively easy to distinguish peaceful and hostile, such a ban would include the nuclear science itself which indeed paved the way for nuclear weaponry. By excluding the peaceful use of nuclear energy, the Treaty conditions itself upon and includes the distinction between what is peaceful and what is hostile. Unable to convince the nuclear powers, the effort put forth by the States Parties and individuals, entities, and organizations is worth mentioning.

The Treaty aims to be universal, universally agreed, universally adopted, universally implemented. However, the main impediment thereto is its being a treaty itself, a legal compromise diplomatically arranged, technically drafted, conventionally dealt. Although the number of voters to the Treaty is huge (122) by any standard, against the backdrop of the states who have not participated nor signaled any compromise with the initiative represented by the international community seen in the UN Conference, such backdrop remains as an obstacle to the realization of the object and purpose of the Treaty itself, and paradoxically it is that obstacle itself that ensures what it is obstacle to. In other words, perhaps, it is in this sense of an obstacle which conditioned the enjoyment in nuclear dealings of 2017. In our opinion, to conceive the enjoyment of ruling experts, repetition is worth to connote the limit of the ban that limits: The nuclear weapons are legally declared illegal, but the ban is not legally binding on nuclear powers who hold nuclear weapons legally.

\section{References}

Aerial Incident of July 27th, 1955 (Isr. v. Bulg.), Preliminary Objections, 1959 I.C.J. Rep. 127 (Mai 26).

Berman, N. (2004-2005). Privileging combat? Contemporary conflict and the legal construction of war. Columbia Journal of Transnational Law, 43, 1.

Bourdieu, P. (1995). Outline of a theory of practice. (R. Nice Trans.). Cambridge: Cambridge University Press.

Case Concerning Armed Activities on the Territory of the Congo (Dem. Rep. Congo v. Uganda), Judgment, 2005 I.C.J. Rep. 168 (December 19).

Carty, A. (1991). Critical international law: Recent trends in the theory of international law. European Journal of International Law, 2, 66.

Corten, O. (2005). The controversies over the customary prohibition on the use of force. European Journal of International Law, 16(5), 803.

Chazel, F., \& Commaille, J. (1991). Normes juridiques et régulation sociale. Paris: LGDJ.

Conséquences juridiques de l'édification d'un mur dans le territoire palestinien occupé, Avis consultatif, 2004 I.C.J. Rep. 136 (Juillet 9).

Deleuze, G. (1993). Différence et répétition (7e édition). Paris: PUF.

Derrida, J. (1981). Dissemination. (B. Johnson Trans.). London, Athlone.

Derrida, J. (1997). Of grammatology. (G. C. Spivak Trans.). Baltimore and London: The John Hopkins University Press.

Fisher, A. S. (1971). Outlawry of war and disarmament. Recueil des Cours, 133, 393.

Frankenberg, G. (2014). Political technology and the erosion of the rule of law. (H. Bauer and E. Elgar Trans.). Northampton.

IAE. List of Member States, https://www.iaea.org/about/governance/list-of-member-states [17.11.2017]

IAEA. (2006). Nuclear forensics support: Reference Manual. Vienna, IAEA Nuclear Security Series No. 2.

Kennedy, D. (1987). International legal structures. Baden-Baden: Nomos.

Kennedy, D. (2006). Reassessing the humanitarian promise of the international legal tradition. Zeitschrift für Schweizerisches Recht., 125, 133.

Kennedy, D. (2016). A world of struggle. Princeton, Oxford: Princeton University Press.

Kolb, R. (2001). La structure constitutionnelle du droit international public. The Canadian Yearbook of International Law, $39,69$. Legality of Threat or Use of Nuclear Weapons, Advisory Opinion, 1996 I.C.J. Rep. 226 (July 8).

Lyotard, J. F., \& Nancy, J. L. (1985). La faculté de juger. Paris: Minuit.

Military and Paramilitary Activities in and against Nicaragua (Nicar. v. U.S.A.), Judgment, 1986 I.C.J. Rep. 14, 269 (June 27)

[Nicar v. U.S.A.].

Peters, A. (1996). Blinding laser weapons. Medicine, Conflict and Survival, 12, 107. 
Réserves à la Convention pour la prévention et la répression du crime de Génocide, Avis consultatif, 1951 ICJ Rep. 15, 26 (Mai 28) [Reservations Opinion].

Rights of Nationals of the United States of America (France v. United States of America), Judgment, 1952 I.C.J. Rep. 176 (August 27).

Spillmann, K. R., \& Wenger, A. (1999). Arms control and disarmament. Zürich: Eidgenössische Technische Hochschule.

Treaty on the Prohibition of Nuclear Weapons, UN Doc. A/CONF.229/2017/8, 07.07.2017. Available at: http://undocs.org/A/CONF.229/2017/8 [17.11.2017]

Tuzmukhamedov, B. (2015). Legal dimensions of arms control agreements. Recueil des Cours, 37, 327.

UNOLA. (1999). Collection of essays: International law. New York, United Nations.

UN. Conference to negotiate a legally-binding instrument to prohibit nuclear weapons: Item 9, UN Doc. A/CONF.229/2017/L.3/Rev.1. Available

at: https://s3.amazonaws.com/unoda-web/wp-content/uploads/2017/07/A.Conf_.229.2017.L.3.Rev_.1.pdf [17.11.2017]

UN Secretary General. (2017). Multilateral Treaties deposited with Secretary General, Chapter XXVI.9. Available at: https://treaties.un.org/Pages/ViewDetails.aspx?src=TREATY\&mtdsg_no=XXVI-9\&chapter=26\&clang=_en [17.11.2017]

UN Secretary General. (2017). Treaty on the non-proliferation of nuclear weapons, submitted by the USA, the UK and USSR. Available at: https://treaties.un.org/pages/showDetails.aspx?objid=08000002801d56c5 [17.11.2017]

Wehberg, H. (1919). Die internationale Beschränkung der Rüstungen. Stuttgart u. Berlin: Deutsche Verlags-Anstalt.

Weil, P. (1998). “The court cannot conclude definitively...” non liquet revisited. Columbia Journal of Transnational Law, 36, 109.

Zizek, S. (2008). For they know not what they do (2nd ed.). London: Verso. 